\title{
A Review on: In Vitro Cloning of Orchids
}

\section{Dipika Sarmah $^{1 *}$, Swathi Kolukunde ${ }^{1}$, Monoj Sutradhar ${ }^{2}$, Brijesh Kumar Singh ${ }^{2}$, Tapas Mandal ${ }^{1}$ and Nirmal Mandal ${ }^{2}$}

\author{
${ }^{1}$ Department of Floriculture and Landscaping, ${ }^{2}$ Department of Agricultural Biotechnology, \\ Bidhan Chandra Krishi Viswavidyalaya, Mohanpur, West Bengal-741252, India \\ *Corresponding author
}

\begin{tabular}{|c|c|}
\hline & A B S T R A C T \\
\hline Keywords & \multirow{6}{*}{$\begin{array}{l}\text { Orchids are the most fascinatingly beautiful flowers and unique group of plants of nature. } \\
\text { With their exotic shapes, hues and the added advantage of longevity, these flowers of rare } \\
\text { beauty have become increasingly popular in the } 21^{\text {st }} \text { century. They belong to the } \\
\text { Orchidaceae family and consisting } 600-800 \text { genera and } 25,000-35,000 \text { species. Today } \\
\text { growing orchid is more than just a hobby, it is an international business covering around } \\
10 \% \text { of the world floriculture trade. Especially, some of the exquisitely rare hybrids of } \\
\text { orchid are among the top ten cut flowers. It has become possible by adopting in vitro tissue } \\
\text { culture techniques for their rapid multiplication. Since, orchids are strictly out breeders, } \\
\text { seed propagation results in unwanted heterozygous types. So, vegetative propagation } \\
\text { techniques require accurate regeneration protocol for obtaining in vitro cultured true to } \\
\text { type plants. In fact, the technical aspect of micropropagated orchids have improvised } \\
\text { significantly in past few years. But the loop holes in micropropagation stems from the } \\
\text { somaclonal variation, phenolic compound exudation explants, hardening and so on. We } \\
\text { endeavour to include the major contribution based on orchid tissue culture starting from } \\
\text { the pioneering work of Rotor, G. } 1949 \text { to Balilashaki et al., } 2014 \text {. }\end{array}$} \\
\hline & \\
\hline & \\
\hline $\begin{array}{l}\text { Protocorm like } \\
\text { bodies, Cymbidium, } \\
\text { Denrobium and } \\
\text { Phalaenopsis. }\end{array}$ & \\
\hline Article Info & \\
\hline $\begin{array}{l}\text { Accepted: } \\
\text { 21 July } 2017 \\
\text { Available Online: } \\
\text { 10 September } 2017\end{array}$ & \\
\hline
\end{tabular}

\section{Introduction}

"If nature ever showed her playfulness in the formation of flowers, this is visible in the most striking way among the orchids. ". Most of us would definitely echo this view of the seventeenth century German botanist Jakol Breyne (Davis et al., 1983). Orchids are being praised as one of the most favourite cut flower and an ornamental plant all around the world for their exotic beauty and long lasting shelf life. Currently, a multimillion dollar orchid industry is booming in countries like Australia, Malaysia, Singapore, Thailand and several others. Currently, the orchids hold sixth position among the top ten cut flowers of the world and Cymbidium orchid in particular contributes $3 \%$ of the total cut flower production (De and Debnath, 2011).

Though orchids are grown primarily as ornamentals, some are employed as herbal medicines and food (tubers of Cynorchis and Eulophia) by many different cultures and tribes (Arditti, 1992). Some orchid species of the Macodes, Ludisia, Anoectochilus and Goodyera, genera are known as jewel orchids because of their beautiful foliage. Few orchids are also being used as spice, e.g. Vanilla. 
The Indian orchid diversity consisting approximately 158 genera and 1331 species are thriving upto an elevation of $5000 \mathrm{~m}$. Most of terrestrial orchids are grown in humus rich moist shady locations of North Western India whereas, hills of Western Ghats harbour most of the rare small flowered orchids. The North Eastern hilly regions of India are heaven for epiphytic orchids which can be found to grow upto an altitude of 2000 $\mathrm{m}$ from sea level (Chowdhery, 2009). Some of native Indian genera like Arachnis, Cymbidium, Dendrobiumare, Paphiopedilum, Vanda are largely cultivated for cut flower production. Cymbidium is popularly grown in Arunachal Pradesh, Assam Darjeeling and Sikkim. However, tropical orchids are found in some parts Kerala and Tamil Nadu. These native Indian orchid species rule the market for high ornamental value and also for breeding purposes. In terms of export economy, winter and spring flowering orchids of temperate regions are more preferable because quality deterioration during transport is less during colder months December to May.

\section{The status of orchid trade and industry}

"Orchid growing has not fully achieved the transaction from a hobby to an industry" James Shoemaker, 1957. But in twenty first century, it would be completely unfair to address orchid cultivation as a mere hobby, but it has flourished into an international industry business (Griesbach, 2002). Today orchids are dominating the cut flower and potted plant commerce due to its long lasting charm, high productivity, right seasonal blooming, convenient packing and transportation (De et al., 2014). The largest exporters of potted orchids are Taiwan, Brazil, Italy, Thailand, Japan, New Zealand and UK whereas, United States stands first in import (Chugh et al., 2009). Asia is the main source of orchid to enter the world. The economy of many ASEAN (Association of the South East Asian Nations) countries are substantially benefitted by industrial production of Dendrobium, Phalaenopsis, Oncidium and Cymbidium orchids (Hew, 1994; Laws, 1995). During 2005 in United States, potted orchids gained a total wholesale value of US\$ 144 million (U.S. Department of Agriculture, 2006) and Phalaenopsis sp. earned $75 \%$ of all the orchids sold replacing Cattleya (most popular type of 1980s) Griesbach, 2002. Thailand, which is the world's sixth largest exporter of cut flowers, earns US\$ 30 million a year from orchid exports, and Singapore earns US\$ 16 million a year (Reddy, 2008).

The value of fresh cut orchids and buds trade during 2007-2012 is concise in table 1 . In 2012 , the total transaction of the global orchid trade reached US \$504 million with more than 40 exporting and 60 importing countries around the world.

The top most orchid exporting countries are Netherlands (39.67\%), Thailand $(28.41 \%)$, Taiwan (10\%), Singapore (10\%) and New Zealand $(6 \%)$ whereas, importing countries are mainly Japan (30\%), UK (12\%), Italy $(10 \%)$, France $(7 \%)$ and the USA (6\%). Among the total cut flower orchid species of world, $85 \%$ are Dendrobium, $15 \%$ are Phalaenopsis and Cymbidium (Cheamuangphan et al., 2013).

According to Chugh et al., (2009), the annual flower production of India is around 1000 tonnes with a miniscule international market share of $0.01 \%$. Even though since the last few years orchids have made their presence felt in the Indian cut flower trade, orchid cultivation and commerce in India is still at a budding stage. According to the Indian tissue culture market survey by Biotech Consortium India Limited (Department of Biotechnology) and Small Farmers' Agri-Business 
Consortium, 2005, Dendrobium sp. (as cut flower) and Vanilla (for spice) are the most important plants suitable for tissue culture propagation in India. Varied agroclimatic zones, cheap labour, ever growing high end consumer markets make it a highly profitable proposition to grow orchids in India (Singh et $a l ., 2008)$. So far, the north-eastern hill region and few parts of Kerala and Karnataka are the only Indian regions which are being used for commercial orchid production. In reality, the cut flower orchid business continuously gets hampered by lack of control in airports, huge quantities of diseased and rejected cut flowers, even toxic dye treated flowers get dumped in Indian cities for biosafety suspicion (De, 2008).

\section{Trends in growth of some important} commercial orchids

\section{Cymbidium spp.}

The semi-terrestrial orchid Cymbidium is originated from tropical and subtropical Asia. But, they are mainly grown in winter and spring blooming seasons and in cooler climates at high elevations. The most popular Cymbidium orchid growing countries are Philippines, Borneo islands, Japan, Malaysia, China, North Australia and North Eastern India. They are highly prized as cut flowers, potted plants, hanging baskets, herbal medicines and as genetic resources. It has been considered as top commercial orchids in Europe since many years. They fetch the highest price in the international markets of Singapore, Japan and the Dutch market. In India, the hills of Sikkim, Darjeeling and Arunachal Pradesh with cooler nights and monsoonal rain of summer set the most favourable climate for ideal cultivation of Cymbidium. Hybrid Cymbidium orchids (more than 350) are commercially grown in around 25 ha of land in Sikkim with 5 lakhs spikes of annual production. East Sikkim has already been declared as Agri Export Zone exclusively for production of Cymbidium orchids (De et al., 2014). There is a huge export potential of orchid export industry from north eastern hill region especially Sikkim with improvement in supporting industries like packaging, cold storage and transportation which may also generate better employment opportunity in those underprivileged states

\section{Dendrobium spp.}

Dendrobiums come under one of the most common type of orchids which are accepted in both cut flower and potted plant form around the world. These mesmerizing orchids are known for their vast range of flower colour, size, shape and floriferousness. The everlasting orchids are also available throughout the year. The most popular potted Dendrobium growing regions in the United States are Hawaii, California and Florida. The wholesale value of sales for this commodity in Hawaii has been found for several decades. In the Netherlands, production of potted orchids is now 40 to 50 million units with Dendrobium increasing in popularity. Imports from Thailand, the world's largest exporter of tropical cut orchids and second largest supplier to the EU, accounted for $22 \%$ of supplies to the EU. Thailand holds a particularly strong position in Dendrobium orchids (De et al., 2014).

\section{Phalaenopsis spp.}

Phalaenopsis is the second most important cut flower and potted plant orchid of the world. It is gaining popularity due to ease in cultural practices and diverse flower colour, shape, size and delicacy. It is commercially grown in Germany, Japan, Netherlands, Taiwan and United States. In USA, around 13,500,000 Phalaenopsis were sold during 2005 and currently it shares $75 \%$ of the 
purchased orchids. The export value of Phalaenopsis from Taiwan to the United States increased from \$8 million in 2005 to \$ 13 million in 2006 (De et al., 2014).

\section{In vitro clonal propagation of orchids}

The concept of in vitro culture was first proposed by Haberlandt (1902) and explicitly verified for the first time by Steward et al., (1958). In this technique, the totipotency of plant is exploited to multiply the plants from their meristematic cells in controlled invitro condition. It can also be called as tissue culture, cell culture or organ culture under in vitro condition (Debergh and Read, 1991). Large scale proliferation of healthy and disease free quality propagating material can be obtained with this technique. It has also been proved to be economically viable option for efficient biodiversity and gene pool conservation.

The orchids are highly heterozygous and their vegetative propagation through division, splitting of shoots and kiekis are very slow which yields only a meagre number of plants even after five to six years. Although orchid seeds are produced in large number, i.e., two to three millions per capsule, as they lack endosperm, they germinate very poorly in nature.

The propagation and cultivation of orchids was revolutionized by the discovery of Knudson (1992), showed that orchid seeds can germinate on a relatively simple medium containing sucrose. This became the standard procedure for germinating orchid seeds. The earliest report of using tissue culture techniques in the clonal propagation of orchid was that of Rotor (1949). Observing that plantlets could develop from buds of Phalaenopsis, he cultured flower stalk nodes in vitro and obtained some plantlets. The tremendous development made in orchid industry through the wide applications of tissue culture techniques owes its credit to Morel (1960) who was the first to magnificently initiate Cymbidium meristem tip culture. The orchids are the symbol of the first successful mass micropropagated floriculture crop.

\section{Factor influencing in vitro cloning}

\section{Explant}

\section{Explant sterilization}

Explant sterilization is most important for in vitro propagation. Bacterial and fungal infections can be eliminated by proper immersion time of explants in the sterilization agents (Yildiz and Er, 2002). Maximum survival percentage of cultures of Dendrobium nobile var. Emma white with limited necrosis and infection was observed when sterilization of axillary buds was done for $8 \mathrm{~min}$ with $10 \%(\mathrm{v} / \mathrm{v})$ (Asghar et al., 2011).

Balilashaki et al., (2014) carried out a study to identify the best method for sterilization of nodes of Phalaenopsis amabilis cv. Cool 'Breeze' with different concentration of sodium hypochlorite and they found that best assembly for sterilization is about $7 \%$ sodium hypochlorite.

\section{Type of explant}

Rotor, 1949 first demonstrated that Phalaenopsis plantlets development from the buds of inflorescence stalks through micropropagation. The Morel, 1960 revolutionized commercial propagation of orchids by shoot meristem culture techniques. However, as the techniques entails the sacrifice of the mother plant or its entire new organ growth, organ culture (leaves, roots, inflorescence stalks) is the fast emerging as an 
ideal method for cloning elite orchids (Arditti, 1977).

\section{Meristem/ shoot tip culture for in vitro propagation}

The technique of apical meristem culture for virus-free production of dahlias was first published by Morel and Martin (1952) and later on Morel, (1960) did the same for production of Cymbidium. However, Wimber (1963) was the true pioneer to establish the detailed protocol for in vitro production of Cymbidium using meristem culture as starting material.

Steward and Mapes (1971) gave an account of the growth and development of aseptically cultured cells and tissues showing that Cymbidium plants could be indefinitely multiplied as cell cultures which gave rise to PLBs. Infact, the time expenditure for transformation of free cells into abundant protocorms were comparatively very long (about 9 months). But, each of these obtained protocorms was capable of giving rise to a healthy plant. Since then, shoot tips are effectively being used for the induction of PLBs and shoot buds of many orchids (Table 2).

Vanda coerulea was rapidly multiplied by shoot tip culture technique and clonally propagated in forest segments of the Western Ghats (Seeni and Latha, 2000). Kalimuthu et al., (2006) reported initiation, multiplication, elongation and rooting of Vanilla using MS + $1 \mathrm{mg} / \mathrm{L} \mathrm{BAP}+150 \mathrm{mg} / \mathrm{L} \mathrm{CW}$ media under invitro condition.

Success in callus cultures in which the callus can be maintained for a prolonged period through subsequent subculture has been limited to a few orchids (Ishii et al., 1998; Chang and Chang, 1998; Roy and Banerjee, 2003). It is because of the uncertainties related to callus induction, necrosis, restricted growth and proliferation (Roy et al., 2007). Roy and Banerjee (2003) reported embryogenic callus induction from shoot tip explant of Dendrobium fimbriatum Lindl. var. Oculatum in modified $\mathrm{KC}$ medium +0.5 $\mathrm{mg} / \mathrm{L} \mathrm{NAA}+1 \mathrm{mg} / \mathrm{L}$ BAP). However, Roy et al., (2007) observed the same response of $D$. chrysotoxum in modified MS medium +2 mM TDZ/BAP.

It is a matter of fact that only two (Vanda and Vanilla) among all of the shoot tip culture adopted orchids are monopodial orchids which have a single upright shoot with indeterminate growth and absence of rhizomes (Arditti, 1992). So, growth and development retardation of mother plant is common in shoot tip culture of monopodial orchid. Therefore, it is not always considered to be economical (Philip and Nainar, 1986). However, sympodial orchids like Dendrobium, Cymbidium, Arundina, Phaius and Anoectochilus may be more adaptive towards shoot tip culture.

\section{Leaf segment culture}

Leaf segment explants are advantageous over other type of explants, since they are easy to obtain without sacrificing the mother plant and available around the year. Wimber (1965) first used Cymbidium leaf tissue culture for PLBs production. Seeni and Latha, 1992 successfully regenerated endangered Renanthera imschootiana Rolfe (Red Vanda) from leaf tissue culture. The direct adventive shoot bud formation was observed in the bases of the leaves. But there was no such response from chlorophyllous distal parts of the leaves of both flowering and in vitro grown plants. The mature leaves of Vanda coerulea (Blue Vanda) also could not regenerate shoot buds or PLBs (Seeni and Latha, 2000). The influence of tissue juvenility in terms of donor leaf size on the regeneration competence (frequency of response and number and nature of 
regenerants) was also reported in Vanda Kasem's Delight 'Tom Boykin' (Vij et al., 1994) and Vanda coerulea Griff. (Vij and Aggarwal, 2003) foliar cultures. Since, there was variation in the response of juvenile and mature leaves under same in vitro conditions, it clearly reflected the effect of explant source and physiological age (Murthy and Pyati, 2001).

Chen and Chang, 2001 reported deleterious effect on embryo formation from Oncidium leaf explants by auxins (IAA, IBA, NAA and 2, 4-D). However, they found promotive effect of cytokinins like 2iP, zeatin, Kin, BAP and TDZ in embryogenesis. They also found somatic embryogenesis promotion by ancymidol, paclobutrazol and demotion by GA3 and cycocel (Chen and Chang, 2003a). They again studied with auxin transport inhibitors (TIBA and quercetin) and auxin antagonist (PCIB). They found somatic embryogenesis from leaf tip explant retardation by IAA and 2, 4-D (Chen and Chang, 2004).

Ethylene precursor (ACC 1-amino cyclo propane-1-carboxylic acid) was shown to have a dose dependent response with lower concentrations $(5 \mathrm{mM}$ and $10 \mathrm{mM})$ significantly retarding and higher concentrations (20-50 mM) enhancing direct embryo formation. Ethylene inhibitors $\mathrm{AgNO}_{3}$ and $\mathrm{CoCl}_{2}$ retarded embryo formation suggesting that ethylene may be necessary for direct somatic embryogenesis (Chen and Chang, 2003b). The frequency of embryogenesis and the average number of embryos per embryo-producing explant were both reported to be affected by explant orientation. Chen and Chang (2002) observed higher somatic embryogenesis response with adaxial side up orientation than abaxial side up orientation. The use of leaf explants for effective micropropagation relies on factors such culture composition, growth regulators, leaf source (in vitro/in vivo), to be used portion, orientation and age. These above factors standardization time and cost requirement strictly restricts mass scale industrial micropropagation of orchids using leaf explants (Table 3).

\section{Inflorescence axis and flower bud culture}

Rotor (1949) first initiated the use of orchid inflorescence segment as explant in Phalaenopsis cultures using flower stalks in vitro. This technique is advantageous over others, since there is no requirement of sacrificing the whole plant to obtain the explant.

Moth orchid Phalaenopsis is monopodial, which mostly was mass propagated by this technique. This popular orchid genus is very difficult to propagate vegetatively. Out of the several techniques that have been developed for in vitro propagation of this popular orchid, most involve culturing the dormant buds present at the basal part of the inflorescence (Griesbach, 1983).

The in vitro cultured flower stalk buds have three modes of growth: dormant, vegetative and reproductive in most of the orchids. BA $(4.40 \mathrm{mg} / \mathrm{L})$ and NAA (1 mg/L) added to the MS medium promoted the large number of shoots derived from the inflorescence stalk node of Phalaenopsis (Balilashaki et al., 2014). Except Phalaenopsis, inflorescence segment generated micropropagation of few other orchids is given table 4 .

The regeneration response of orchid inflorescence explants also depends on the explant age. The younger source obtained explants of Dendrobium Miss Hawaii, Phalaenopsis Capitola, Oncidium Gower Ramsey, Ascofinetia and Ponerorchis graminifolia Rchb. f. have been responding well under invitro condition (Nuraini and Shaib, 1992 and Mitsukuri et al., 2009). 


\section{Culture medium}

The composition of the culture media affects the induction, regeneration, number and form of Phalaenopsis regenerants. Kosir et al., (2004) obtained Phalaenopsis sp. direct shoot regeneration without callus formation from flower stalk's dormant buds on different media composition. They found rapid micropropagation of a large number of vegetative shoots without roots 160 days after inoculation in media supplemented with 2 $\mathrm{mg} / \mathrm{L}$ of 6-benzylaminopurine (BAP) and 0.5 $\mathrm{mg} / \mathrm{L}$ of $\alpha$-naphthalene acetic acid (NAA). However, media supplemented with 4.41 $\mathrm{mg} / \mathrm{L}$ BAP and $1 \mathrm{mg} / \mathrm{L}$ NAA ceased the regenerants to elongate. The highest multiplication of regenerants was observed in media containing $2 \mathrm{mg} / \mathrm{L} \mathrm{BAP}$ and lower nitrogen concentration.

Sinha and Jahan, 2011 reported maximum Phalaenopsis amabilis PLBs production after 12 weeks of culture in media containing $1 / 2 \mathrm{MS}, 2 \%$ (w/v) sucrose, $2 \mathrm{~g} / \mathrm{L}$ peptone, $10 \%$ (v/v) coconut water, $1 \mathrm{~g} / \mathrm{L}$ activated charcoal, 6-BA@ 2.0 mg/L and NAA @ $0.5 \mathrm{mg} / \mathrm{L}$.

Chen et al., (2002) cultured leaf explants of Paphiopedilum philippinense hybrid's (hybrid PH59 and PH60) in modified MS medium (half strength macro and full strength micro elements) free of plant growth regulator in darkness. They observed adventitious shoot formation from wound regions of leaf within 1 month of culture.

Aktar et al., (2008) reported 1/2 MS medium to be best suitable for in vitro regeneration of Dendrobium orchid. They also observed that different kinds of media composition with organic additives significantly influence the explant growth, development and regeneration.

\section{Carbon source}

The carbon sources of culture medium supplement the low $\mathrm{CO}_{2}$ concentration, light energy deficiency and osmoregulation maintenance prevalent under in vitro conditions.

Rittirat et al., (2012) used wounded protocorm segment explants of Phalaenopsis cornu-cervi (Breda) Blume and Rchbf. in 1/2 MS medium supplemented with $0.1 \mathrm{mg} / \mathrm{L}$ NAA and $0.1 \mathrm{mg} / \mathrm{L}$ TDZ for PLB production. The obtained PLBs produced best quality plantlets (without browning or necrotic tissues) within 5 months of culture in New Dogashima (ND) medium supplemented with $0.2 \% \mathrm{AC}$ and $4 \%$ sucrose. There was $100 \%$ plantlet survival and those were transplanted into pots containing sphagnum moss, placed in a net house with about $60 \%$ shading and $80 \%$ relative humidity.

Table.1 Value of fresh cut orchids and buds global trade (2007-2012) (Unit: Million US\$)

\begin{tabular}{ccccccc}
\hline Year & 2007 & 2008 & 2009 & 2010 & 2011 & 2012 \\
\hline Import & $233,734,023$ & $252,647,645$ & $232,568,129$ & $251,445,523$ & $265,702,077$ & $267,196,847$ \\
Export & $230,470,421$ & $238,702,950$ & $217,781,745$ & $227,389,789$ & $244,996,271$ & $237,543,797$ \\
\hline Total & $464,204,444$ & $491,350,595$ & $450,349,874$ & $478,835,312$ & $510,698,348$ & $504,740,644$
\end{tabular}


Table.2 Micropropagation of some orchids using shoot tip explants

\begin{tabular}{|c|c|c|c|c|}
\hline Orchid species & Medium composition & $\begin{array}{l}\text { Regenerants } \\
\text { (PLB/shoot } \\
\text { bud) }\end{array}$ & $\begin{array}{c}\text { Source of } \\
\text { explant } \\
\text { (in vitro/in vivo) }\end{array}$ & References \\
\hline Anacamptis pyramidalis (L.) Rich. & $\mathrm{MS}+(\mathrm{NAA} / \mathrm{IBA} / \mathrm{IAA} ; 0.5-1 \mathrm{mg} / \mathrm{L})+\mathrm{CW}$ & PLBs & NA & Morel (1970) \\
\hline Anoectochilus formosanus Наy. & $\begin{array}{l}\text { Hyponex medium }+1 \mathrm{mgdm}^{-3} \mathrm{BAP} / \mathrm{L}- \\
2 \mathrm{mgdm}^{-3}\end{array}$ & Shoot buds & In vivo & Ketet al., (2004) \\
\hline Arundina bambusifolia Lindl. & $\begin{array}{l}\text { Raghavan and Torrey's (1964)medium N } \\
\text { and } \mathrm{N} \text { medium }\end{array}$ & Shoots & In vitro & $\begin{array}{l}\text { Nagaraju and } \\
\text { Parthasarathy (1995) }\end{array}$ \\
\hline Cymbidium aloifolium (L.) Sw. & $\mathrm{VW}+5.0 \mathrm{mg} / \mathrm{L} \mathrm{NAA}$ & PLBs & In vitro & Devi et al., (1997) \\
\hline $\begin{array}{l}\text { Cymbidium atropurpureum } \\
\text { (Lindley) Rolfe. }\end{array}$ & $\mathrm{MS}+2.5 \mathrm{mg} / \mathrm{L} \mathrm{BAP}$ & PLBs & NA & $\begin{array}{l}\text { Subramanium and } \\
\text { Taha (2003) }\end{array}$ \\
\hline D. wardianum R. Warner & $\mathrm{VW}+1 \mathrm{mg} / \mathrm{L} \mathrm{BAP}+1.5 \mathrm{mg} / \mathrm{L} \mathrm{NAA}$ & PLBs & In vivo & $\begin{array}{l}\text { Sharma and Tandon } \\
\text { (1992) }\end{array}$ \\
\hline Dendrobiumcv. Sonia & $1 / 2 \mathrm{MS}+1 \mathrm{mg} / \mathrm{L} \mathrm{BAP}+7.5 \% \mathrm{CW}$ & Shoot buds & In vivo & Sheelaet al., (2004 \\
\hline Dendrobium Joannie Ostenhault & $\mathrm{VW}+15 \% \mathrm{CW}$ & PLBs & - & $\begin{array}{l}\text { Sharon and } \\
\text { Vasundhara (1990) }\end{array}$ \\
\hline $\begin{array}{l}\text { Phaiustankervilleae (Banks ex } \\
\text { Aiton)Blume }\end{array}$ & $\begin{array}{l}\text { Raghavan and Torrey's (1964)basal } \\
\text { medium }\end{array}$ & PLBs & In vitro & $\begin{array}{l}\text { Nagaraju and } \\
\text { Parthasarathy (1995) }\end{array}$ \\
\hline Vanilla planifoliaAndr. & $\mathrm{MS}+1 \mathrm{mg} / \mathrm{L} \mathrm{BAP}+150 \mathrm{ml} / \mathrm{L} \mathrm{CW}$ & Shoots & In vivo & $\begin{array}{l}\text { Kalimuthuet al., } \\
\text { (2006) }\end{array}$ \\
\hline
\end{tabular}


Table.3 Micropropagation of some orchids using leaf explants.

\begin{tabular}{|c|c|c|c|c|}
\hline Orchid species & Medium composition & $\begin{array}{l}\text { Regenerants } \\
\text { (PLB/shoot } \\
\text { bud) }\end{array}$ & $\begin{array}{l}\text { Source of } \\
\text { explant } \\
\text { (in vitro/in } \\
\text { vivo) }\end{array}$ & References \\
\hline Aerides crispum L. & $\mathrm{MS}+2.0 \mathrm{mM}$ BAP & PLBs & In vitro & $\begin{array}{c}\text { Sheelavanthmathet } \\
\text { al., (2005) }\end{array}$ \\
\hline $\begin{array}{l}\text { Aerides multiflora } \\
\text { Roxb. }\end{array}$ & $\begin{array}{l}\mathrm{MPR}+2 \mathrm{mg} / \mathrm{L} \mathrm{BAP}+ \\
0.5 \mathrm{mg} / \mathrm{L} \text { NAA }\end{array}$ & PLBs & In vitro & $\begin{array}{l}\text { Vijet al., } \\
(2004 \mathrm{a}, \mathrm{b})\end{array}$ \\
\hline $\begin{array}{l}\text { Dendrobium Cheingmai } \\
\text { Pink }\end{array}$ & $1 / 2 \mathrm{MS}+18.16 \mathrm{mM} \mathrm{TDZ}$ & $\begin{array}{l}\text { Somatic } \\
\text { embryos }\end{array}$ & In vitro & $\begin{array}{l}\text { Chung et al., } \\
\text { (2005) }\end{array}$ \\
\hline $\begin{array}{l}\text { Dendrobium hybrids } \\
\text { (Sonia } 17 \text { and } 28 \text { ) }\end{array}$ & $\mathrm{MS}+44.4 \mathrm{mM} \mathrm{BAP}$ & PLBs & In vitro & $\begin{array}{c}\text { Martin and } \\
\text { Madassery (2006) }\end{array}$ \\
\hline MicroperapallidaLindl. & $\begin{array}{l}1 / 2 \mathrm{MS}+2 \mathrm{mg} / \mathrm{L} \mathrm{NAA}+2 \\
\mathrm{mg} / \mathrm{L} \mathrm{BAP}\end{array}$ & PLBs & In vitro & $\begin{array}{c}\text { Bhadra and } \\
\text { Hossain (2004) }\end{array}$ \\
\hline $\begin{array}{l}\text { Phalaenopsis Little } \\
\text { Steve }\end{array}$ & $1 / 2 \mathrm{MS}+4.54 \mathrm{mM} \mathrm{TDZ}$ & $\begin{array}{l}\text { Somatic } \\
\text { embryos }\end{array}$ & In vitro & Kuoet al., (2005) \\
\hline Vanilla planifolia Andr. & $\begin{array}{l}\mathrm{MS}+4.52 \mathrm{mM} 2,4-\mathrm{D}+ \\
2.22 \mathrm{mM} \mathrm{BAP} \\
\mathrm{MS}+4.52 \mathrm{mM} 2,4-\mathrm{D}+ \\
2.22 \mathrm{mM} \mathrm{BAP}\end{array}$ & $\begin{array}{l}\text { Callus } \\
\text { Shoots from } \\
\text { the callus }\end{array}$ & In vivo & $\begin{array}{l}\text { Janarthanam and } \\
\text { Seshadri (2008) }\end{array}$ \\
\hline
\end{tabular}

Table.4 Micropropagation of some orchids using inflorescence explants

(Obtained from in vivo source)

\begin{tabular}{|c|c|c|c|}
\hline Orchid species & Medium composition & $\begin{array}{c}\text { Regenerants } \\
\text { (PLB/shoot bud) }\end{array}$ & References \\
\hline Aranda Deborah (Arachis & $\mathrm{KC}+1 \mathrm{mg} / \mathrm{L} \mathrm{BAP}+\mathrm{CW}$ & PLBs & Goh and \\
\hline hookeriana (Rcbh. f.) & & & Wong (1990) \\
\hline \multicolumn{4}{|l|}{ Rchb. f. $\times$ Vanda lamellate } \\
\hline \multicolumn{4}{|l|}{ Lindl.) } \\
\hline Epidendrum radicans Pav. Lindl. & $1 / 2 \mathrm{MS}+0.1 \mathrm{mg} / \mathrm{L} \mathrm{TDZ}$ & $\begin{array}{l}\text { PLBs/shoot } \\
\text { buds }\end{array}$ & $\begin{array}{l}\text { Chen et al., } \\
\text { (2002) }\end{array}$ \\
\hline Oncidium Sweet Sugar & $\begin{array}{l}1 / 2 \mathrm{MS}+5 \mathrm{mg} / \mathrm{L} \mathrm{BAP}+5 \\
\mathrm{mg} / \mathrm{L} \mathrm{NAA}\end{array}$ & PLBs & $\begin{array}{l}\text { Chen and } \\
\text { Chang (2000) }\end{array}$ \\
\hline Ponerorchis graminifolia $\mathrm{Rchb} . \mathrm{f}$. & $\begin{array}{l}1 / 2 \mathrm{MS}+4.44 \mathrm{mM} \mathrm{BAP}+ \\
0.54 \mathrm{mM} \text { NAA }\end{array}$ & Shoot buds & $\begin{array}{l}\text { Mitsukuriet } \\
\text { al., (2009) }\end{array}$ \\
\hline
\end{tabular}


Lim and Chong, 2014 identified autotrophic, mix autotrophic-heterotrophic and heterotrophic growth in Phalaenopsis deliciosawas seedlings with $20 \mathrm{~g} / \mathrm{L}$ optimum sucrose concentration. This concentration is recommended when raising $P$. deliciosa seedlings to retain photosynthetic activity for better survival during acclimatization.

Novotna et al., (2007) found that best seedling development of Dactylorhiza species with glucose and sucrose at concentration of $10 \mathrm{~g} \mathrm{dm}^{-3}$ each. Later the improvement of shoot growth rate and shoot length was enhanced by cytokinins $\mathrm{N}_{6}$-(2-isopentenyl) adenine or $\mathrm{N}_{6}$-benzyladenine and their combination with auxin indole butyric acid (IBA).

Jawan et al., (2010) found that Vanda dearei protocroms prefer sucrose as compared to fructose and glucose. The media containing $1 / 2 \mathrm{MS}, 2 \%(\mathrm{w} / \mathrm{v})$ or $4 \%(\mathrm{w} / \mathrm{v})$ sucrose is best for seedling formation.

Baque et al., (2011) reported $15 \mathrm{~g} / \mathrm{L}$ sucrose concentration to be most suitable for 'Bukduseong' $\times$ 'Hyesung', while 15 and 30 $\mathrm{g} / \mathrm{L}$ sucrose were regarded as an optimal concentration for in vitro growth of the plantlets of 'Chunkwang' $\times$ 'Hyesung' hybrid. They also observed increasing plantlets abnormality and root growth with higher sucrose concentration $(60 \mathrm{~g} / \mathrm{L})$.

\section{Plant growth regulators}

According to Krikorian (1982) the success of an in vitro system is directly influenced by the correct growth regulator used and its optimum concentration. The commonly used plant growth regulators belong to the auxin and cytokinin groups. Tokuhara and Mii (1993) reported that the combination and appropriate concentration of hormones $\alpha$-naphthalene acetic acid (NAA), 6-benzylamino purine
(BAP), macro and micro elements in the culture medium are major factors for commercial Phalaenopsis micropropagation.

Niknejad et al., (2011) documented Phalaenopsis gigantean micropropagation protocol with PLB and leaf explant. They observed calli and PLBs development within 6 weeks of culture in New Dogashima Medium (NDM) supplemented with TDZ @ of $0.5 \mathrm{mg} / \mathrm{L}$ NAA @ of $0.1 \mathrm{mg} / \mathrm{L}$.

Habiba et al., (2014) investigated in vitro organogenesis of Epidendrum 'Rouge Star No.8' PLBs with different types of cytokinins. They used three types of cytokinins including kinetin (Kin), 6benzylaminopurine (BA) and 2-isopentenyl adenine (2ip) which was evaluated with various concentrations of $0,0.1,1$ and 10 $\mathrm{mg} / \mathrm{L}$ in modified MS medium. They reported that three cytokinins at all concentrations were found significantly to enhance organogenesis of PLBs in Epidendrum 'Rouge Star No. 8' orchid except $10 \mathrm{mg} / \mathrm{L}$ of BA treatment when compared with control and $0.1 \mathrm{mg} / \mathrm{L}$ kinetin gave highest number of PLB. In case of shoot formation, they observed highest number of shoots per explant at $1 \mathrm{mg} / \mathrm{L}$ BA but the shoot formation rate $(66.7 \%)$ was highest at $1 \mathrm{mg} / \mathrm{L}$ kinetin. Results showed that kinetin enhanced root induction when compared with 2ip and BA. MS medium supplemented with BA (4.40 $\mathrm{mg} / \mathrm{L})$ and NAA (1.0 $\mathrm{mg} / \mathrm{L})$ promoted maximum number of shoot formation of Phalaenopsis amabilis at (Balilashaki et al., 2014).

The Dendrobium transparens L. immature embryos from 120 days old capsule were germinated on $1 / 2$ MS supplemented with 1 $\mathrm{mg} / \mathrm{L} \mathrm{NAA}+2 \mathrm{mg} / \mathrm{L}$ BAP and same hormonal combination showed highest number of multiple shoot while rooting with 1 mg/L IAA (Suntibala and Kisore, 2009). 
Asghar et al., (2011) reported that $2 \mathrm{mg} / \mathrm{L}$ BAP produced maximum number of shoots, while $1.5 \mathrm{mg} / \mathrm{L}$ of Kin exhibited the highest shoot length of Dendrobium nobile var. Emma white. IBA $(2 \mathrm{mg} / \mathrm{L})$ increased the rooting percentage $(97.5 \%)$ more efficiently than NAA. However, necrotic yellow shoots were observed treatments with higher concentrations of BAP, Kin $(3.0 \mathrm{mg} / \mathrm{L})$ and CW (300 ml).

Pant and Thapa (2012) reported rapid in vitro micropropagation of Dendrobium primulinum Lindl, an endangered epiphytic orchid. They used small shoot tip explants (0.3 to $0.5 \mathrm{~mm})$ which were previously obtained from in vitro grown seedlings. They observed that BAP $(1.5 \mathrm{mg} / \mathrm{L})+$ NAA $(0.5 \mathrm{mg} / \mathrm{L})$ supplemented MS medium to be most effective for the shoot multiplication and IAA was found to be effective hormone for rooting in comparison to IBA and NAA.

Kumari et al., (2013) developed a protocol for in vitro propagation of commercially important cut flower orchid Dendrobium Sonia (Fa. Orchidaceae) 'Earsakul' with stem nodal explants. They found $1 / 2 \mathrm{MS}$ and $4 \mathrm{mg} / \mathrm{L}$ BA to be best suitable for early bud break. However, they concluded $2.0 \mathrm{mg} / \mathrm{L}$ kinetin+ $0.1 \mathrm{mg} / \mathrm{L}$ NAA in shooting media and 0.5 $\mathrm{mg} / \mathrm{L}$ NAA in rooting media for earliest growth and development.

Devi et al., (2013) adopted different explants for rapid clonal propagation of Aerides odorata Lour. They used $1 / 2 \mathrm{MS}$, thidiazuron (TDZ), 6-benzylaminopurine (BAP) and leaf base as explant. They observed $1.0 \mathrm{mg} / \mathrm{L} \mathrm{TDZ}$ medium to produce PLBs at the leaf base. Highest frequency of calli induction from leaf base explants after 60 days of culture was observed in media containing $2 \mathrm{mg} / \mathrm{L}$ (NAA) and direct shoot regeneration with NAA (2 $\mathrm{mg} / \mathrm{L})$ and BAP (4 mg/L). The media containing $1 / 2 \quad \mathrm{MS}$ and $0.5 \mathrm{mg} / \mathrm{L} \quad \mathrm{NAA}$ generated highest frequency of root induction.
The results also highlighted exogenous auxin dependent embryonic callus proliferation.

Verma et al., (2011) reported that TDZ was the most effective for shoot multiplication of Digitalis lamarckii Ivan. via direct organogenesis than BAP, zeatin and kinetin. Pawar et al., (2012) proved that $0.2 \mathrm{mg} / \mathrm{L}$ $\mathrm{IAA}+2.0 \mathrm{mg} / \mathrm{L}$ zeatin supplemented MS medium is the best regeneration efficient medium tomato (Solanum lycopersicum L.).

\section{Medium supplements}

There are several organic additives like banana extract (BE), carrot juice, coconut water $(\mathrm{CW})$, peptone, potato extract, tomato juice etc. which are reported have beneficial effects on seedling growth in many orchid species like Aranda Deborah (Goh and Wong, 1990), Vanda coerulea (Seeni and Latha, 2000), Vanda spathulata (Decruse et al., 2003), Dendrobium tosaense (Lo et al., 2004). Shivkumar et al., (2005) first suggested the use of peptone for enhancing plant tissues growth and development.

Murdad et al., (2010) determined the effects of three types of sugars as the carbon source and potato homogenate $(\mathrm{PH})$ on in vitro growth and development in vitro derived Phalaenopsis gigantean protocorms. They protocorms developed well within 150 days of culture on media containing either fructose or PH. However, on the media containing both sugar and $\mathrm{PH}$, the protocorms were stunted yellow, pale with lower growth during the culture period. Surprisingly, both of the leaf size and root length of $P$. gigantea seedlings were significantly enhanced when the media only contained sugar.

Sinha and Jahan (2011) documented Phalaenopsis amabilis cv. Golden horizon's in vitro mass clonal propagation. They cultured mature plant derived young leaf explants on $1 / 2$ MS supplemented with $\alpha$ - 
naphthalene acetic acid (0.5 mg/L), N6benzyladenine $(2.0 \mathrm{mg} / \mathrm{L}), 10 \%(\mathrm{v} / \mathrm{v})$ coconut water, $2 \%(\mathrm{w} / \mathrm{v})$ sucrose, $1 \mathrm{~g} / \mathrm{L}$ activated charcoal and $2 \mathrm{~g} / \mathrm{L}$ peptone.

They observed that leafy shoots rooted on the previously mentioned media without growth supplements, where $100 \%$ explants were developed into plantlets with roots within 8 weeks.

$\mathrm{CW}$ is cost effectively employed for the micropropagation of imperative species of orchids due to its endless benefits (Peixe et al., 2007). It is a natural growth promoter which contains higher levels of zeatin, zeatin ribosides, 1,3-diphenylurea (contains cytokinin like activity), auxins, nitrogenous compounds, inorganic elements, organic acids, sugars and their alcohols, peptides, vitamins, amino acids and many other unknown components in its composition (Tokuhara and Mii, 2001; Nasib et al., 2008).George et al., (2008) demonstrated that physiologically active substances presents in $\mathrm{CW}$ promote the cell divisions which further enhance shoot multiplication. Baque et al., (2011) demonstrated effective plantlets growth enhancement in 'Bukduseong' $x$ 'Hyesung' and 'Chunkwang' $\times$ 'Hyesung' hybrids of Calanthe with $50 \mathrm{~m} / \mathrm{L}$ coconut water application.

Kaur and Bhutani (2012) were successful to regenerate and multiply Cymbidium pendulum using protocorms explant under invitro condition in $\mathrm{M}$ medium (Mitra medium) supplemented with banana homogenate, coconut water and peptone. The primary protocorm segments first regenerated into secondary protocorms and differentiated into shoots without any callus stage in between.

They observed regeneration frequency to be significantly higher in organic growth supplement enriched (banana homogenate @ $50 \mathrm{~g} / \mathrm{L}, 10 \%$ coconut water and peptone @ 2 $\mathrm{g} / \mathrm{L})$ medium than control. Vijaykumar et al., (2012) reported higher rate of germination, more number of PLBs, shoots and root formation of Dendrobium aggregatum cultured in MS medium supplemented with $1.5 \mathrm{mg} / \mathrm{L}$ BAP, $3 \%$ sucrose and $15 \%$ coconut water $(\mathrm{CW})$.

Shekarriz et al., (2014) reported that modified $\mathrm{KC}$ medium fortified with $2 \mathrm{~g} / \mathrm{L}$ peptone without $\mathrm{CW}$ showed highest survival percentage of seed of Phalaenopsis hybrid 'Manchester' and germination percentage was observed in $15 \%(\mathrm{v} / \mathrm{v}), 2 \mathrm{~g} / \mathrm{L}$ peptone and modified VW medium. They suggested that Phalaenopsis seeds cultured on a $1 / 2$ MS medium containing $\mathrm{CW}$ and peptone can be used for clone propagation.

\section{Anti-contaminants}

During micropropagation the release of phenolic substances is a very common phenomenon and often adversely affects the response of the explants. Browning or blackening of cultured explants is cause only after the wounding. This activity promoted the oxidation of phenolic substances under the control of polyphenol oxidase. Tanaka and Sakanishi (1977) reported poor regeneration in Phalaenopsis tissue culture because of phenolic compound exudation.

Good growth and development of Phalaenopsis plantlets in vitro were obtained when culture media were supplemented with 0.2\% (w/v) AC (Hinnen et al., 1989; Ernst, 1994). Activated charcoal reduce the phenolic exudates, the beneficial effects of AC could be due to positive stimulation of many development processes (Van Winkle and Pullman, 2006) and phenolic compounds absorbtion. Rittirat et al., 2012 reported Phalenopsis cornu-cerve (Breda) Blume Rchb f. best growth in ND medium supplemented with $4 \%$ sucrose and $0.2 \% \mathrm{AC}$ without callus browning or necrotic tissues. 


\section{Hardening of in vitro grown plant}

Orchids are grown in a special media, since root needs plenty of air around them in all times. The media used should provide support to the plant, supply water and nutrients to the roots and enough air for the roots to breath. Puchooa (2004) suggested that high humidity (about 90\%) around the plantlets for two weeks was essential for hardening of the orchid plantlets. He found $84 \%$ survival rate of Dendrobium plantlets transferred to the green house into baskets containing wood charcoal as wood charcoal provides good drainage and adequate aeration to the roots, which is of primordial importance in the culture of orchids.

The rooted plantlet of Dendrobium microbulbon when transferred to a thermocol cups containing a mixture of sand, soil, brick pieces and charcoal pieces (1:1:4:4) showed $60 \%$ survival rate and the same plantlets grown directly on the tree trunk showed $40 \%$ survival rate after six weeks of their removal from in vitro conditions (Sharma et al., 2006). Suntibala and Kishore (2009) successfully acclimatized Dendrobium tranparens L plantlets in a potting mixture of brick and charcoal (2:1) and more than 90\% of transplanted plants survived under greenhouse condition.

Pant and Thapa (2012) observed that the potting mixture containing coco peat and sphagnum moss in the ratio of 2:1 can sustain the hardening of in vitro rooted plantlets with $70 \%$ of plantlets survival. However, they found maximum $66.67 \%$ survival of Dendrobium Sonia 'Earsakul' in hardening mixture charcoal and brick pieces (@1:1 proportion), transplanted in green house condition.

This review provides an overview of what the authors consider to be the most significant literature in orchid micropropagation (historical aspect - Rotor, G. 1949 to Balilashaki et al., 2014). It is a matter of fact that orchids are aesthetically gorgeous gifts of nature and these beauties are tremendously efficient in holding their flowering phase for a long time unlike any other cut flower present on earth. Fortunately, the commercial demand of these rare breeds has been increasing day by day which may ensure their conservation in coming years. The advanced tissue culture techniques with clonal in vitro micropropagation sounds potential for industrial production of high quality orchid plant material which may earn appreciable level of revenue in international market and strengthen the national economy.

A huge number of research has been done on several kinds of orchid species in vitro micropropagation which are commercially demanded.

But all the protocols developed so far may not be successful on industrial level in terms of economic point of view. Hence, we have attempted to put together most of the available literature of in vitro cloning of orchid using shoot tip, leaf, inflorescence axis and flower bud as explants. This may be helpful in adopting the most suitable protocol for its respective orchid species and also improvising the currently available method for in vitro mass propagation.

Author contribution statement Dipika Sarmah and all of the other authors planned and wrote the review manuscript and table and corresponded for publication.

\section{Acknowledgements}

The authors acknowledge the Bidhan Chandra Krishi Viswavidyalaya, Mohanpur, WB for permitting to access the university central library and for providing 'Institutional Assistantship' during preparing the manuscript. 


\section{References}

Agnihotri, R.K., Mishra J and Nandi SK 2009. Improved in vitro shoot multiplication and rooting of Dendrocalamus hamiltonii Nees ET Arn. Ex Munro: production of genetically uniform plants and field evaluation. Acta Physiol Plant 31: 961967

Aktar, S., Nasirunddin KM and Hossain K 2008. Effects of different media and organic additives interaction on in vitro regeneration of Dendrobium orchid. J Agric Rural Dev 6: 69-7

Arditti, J., 1977. Clonal propagation of orchids by means of tissue culture-a manual. Orchid Biology- Reviews and Perspectives. Cornell University Press USA 203-293

Arditti, J., 1992. Fundamentals of Orchid Biology. John Wiley \& Sons New York.

Arditti, J., and Ernst R 1993. Micropropagation of orchids. Jhon Wiley and Sons New York USA.

Asghar, S., Ahmed T, Ahmed HI and Yaseen M (2011) In vitro propagation of orchid (Dendrobium nobile) var. Emma white. Afr J Biotechnol 10: 3097-3103

Balilashaki, K., Naderi R, Kalantari S and Soorni A (2014) Micropropagation of Phalaenopsis amabilis cv. Cool 'Breeze' with using of flower stalk nodes and leaves of sterile obtained from node cultures. Intel J Farm and Alli Sci 3: 823-829

Baque, A., Shin YK, Elshmari T, Lee EJ and Paek KY (2011) Effect of light quality, sucrose and coconut water concentration on the microporpagation of Calanthe hybrids ('Bukduseong' $\times$ 'Hyesung' and 'Chunkwang' $x$ 'Hyesung'). Aus J Crop Sci 5:12471254.

Bhadra, S.K., and Hossain MM (2004) Induction of embryogenesis and direct organogenesis in Micropera pallida Lindl, an epiphytic orchid of Bangladesh. J Orchid Soc India18: 5-9.

Biotech Consortium India Limited (2005) Potential of tissue cultured plant in domestic market. Summary report on Market Report on Tissue Cultured Plants for Department of Biotechnology and Small Farmers' Agri-Business Consortium.

Chang, C., and Chang WC (1998) Plant regeneration from callus culture of Cymbidium ensuifolium var. Misericors. Plant Cell Rep 17: 251-255

Cheamuangphan, A., Panmanee C and Tanusuchat R (2013) Value Chain Analysis for Orchid Cut Flower Business in Chiang Mai. Business and Information 7-9.

Chen, J.T., and Chang WC (2002) Effects of tissue culture characteristics on direct somatic embryogenesis in Oncidium 'Gower Ramsey'. Plant Cell Tiss Org Cult 69: 41-44

Chen, J.T., and Chang WC (2003a) Effects of $\mathrm{GA}_{3}$, ancymidol, cycocel and paclobutrazol on direct somatic embryogenesis of Oncidium in vitro. Plant Cell Tiss Org Cult 72: 105-108

Chen, J.T., and Chang WC (2003b) 1Aminocyclopropane-1-carboxylic acid enhanced direct somatic embryogenesis from Oncidium leaf cultures. Biol Plant 46: 455-458

Chen, J.T., and Chang WC (2004) TIBA affect the induction of direct somatic embryogenesis from leaf explants of Oncidium. Plant Cell Tiss Org Cult 79: 315-320

Chen, T., Chen J and Cheng W (2002) Plant regeneration through direct shoot bud formation from leaf cultures of Paphiopedilum orchids. Plant Cell Tiss Org Cult 76: 11-15

Chowdhery H J (2009) Orchid diversity in north eastern states of India. J Orchid 
Soc India 23: 19-42

Chugh, S., Guha S and Rao U (2009) Micropropagation of orchids: A review on the potential of different explants. Sci Hortic 507-520

Chung, H.H., Chen JT and Chang WC (2005) Cytokinins induce direct somatic embryogenesis of Dendrobium Chiengmai Pink and subsequent plant regeneration. In Vitro Cell Dev Biol Plant 41: 765-769

Davis, P., Davis J and Huxley A (1983) Wild Orchids of Britain and Europe. The Hogarth Press, London

De, D., (2008) Orchid cultivation: an Entrepreneur's approach. In: National Conference on Orchids: Science and Society, Bangalore, India, pp. 89.

De, L.C., and Debnath NG (2011) Vision 2030.NRC for Orchids, Pakyong, Sikkim, India

De, L.C., Khan AM, Kumar R and Medhi RP (2014) Orchid Farming- A Remunerative Approach for Farmers Livelihood. Int J Sci Res 3: 468-471

Debergh, P.C., and Read PE (1991) Micropropagation. In: Debergh PC and Zimmerman RH (eds.), Micropropagation. The Netherlands: Kluwer Acad Publ 1-13

Decruse, S.W., Gangaprasad A, Seeni S and Menon S (2003) A protocol for shoot multiplication from foliar meristem of Vanda spathulata (L.) Spreng. Indian J Exp Biol 41: 924-927

Devi, H.S., Devi SI and Singh TD (2013) High frequency plant regeneration system of Aerides odorata Lour. Through foliar and shoot tip culture. Not Bot Horti Argobo 41: 169-176

Ernst, R., 1994. Effects of thidiazuron on in vitro propagation of Phalaenopsis and Doritaenopsis (Orchidaceae). Plant Cell Tiss Org Cult 39: 273-275

George, E.F., Hall MA and Deklerk GJ (2008) Plant propagation by tissue culture. Springer 1: 206-217

Goh, C.J., and Wong PF (1990) Micropropagation of the monopodial orchid hybrid Aranda Deborah using inflorescence explants. Sci Hortic 44: 315-321

Griesbach, R.J., 1983. The use of indole acetyl amino acid in the in vitro propagation of Phalaenopsis orchids. Sci Hortic 19: 363-366

Griesbach, R.J., 2002. Development of Phalaenopsis orchids for the mass market. In: Jainick, J. and A. Whipkey, A. (Eds.), Trends in New Crops and New Uses. ASHS Press, Alexandria, VA, pp. 458-465.

Haberlandt, G., 1902. Kulturversuche mit isollierten pflanzenzellen.S.B. Naturwissenschaften 111: 69-92

Habiba, S.U., Shimasaki K, Ahasan M and Alam M (2014) Effect of different Cytokinins on In vitro organogenesis in protocorm-like bodies (PLBs) of Epidendrum 'Rouge Star No. 8'. Middle-East J Sci Res 21: 1843-1847

Hew, C.S., 1994. Orchid cut-flower production in ASEAN countries. In: Arditti, J. (Ed.), Orchid Biology: Reviews and Perspectives, John Wiley and Son Inc., New York, pp. 363-401

Hinnen, M.G.H., Pierik, RLM and Bronsema FBF (1989) the influence of macronutrients and some other factors on growth of Phalaenopsis hybrid seedling in vitro. Sci Hortic 41: 105-116

Ishii, Y., Takamura T, Goi M and Tanaka M (1998) Callus induction and somatic embryogenesis of Phalaenopsis. Plant Cell Rep 17: 251-255

Janarthanam, B., and Seshadri S (2008) Plantlet regeneration from leaf derived callus of Vanilla planifolia Andr. In Vitro Cell Dev Biol Plant 44: 84-89

Jawan, R., Gansau JN and Abdullah JO (2010) In vitroculture of borneo's endemic orchid, Vanda dearei. AsPac J 
Mol Biol Biotechnol 18: 203-207

Kalimuthu, K., Senthikumar R and Murugalatha N (2006) Regeneration and mass multiplication of Vanilla planifolia Andr. - A tropical orchid. Curr Sci 91: 1401-1403

Kaur, S., and Bhutani KK (2012) Organic growth supplements stimulants for in vitro multiplication of Cymbidium pendulum (Roxb.) Sw. Hort Sci 39: 4752

Knudson, L., 1992. Non symbiotic germination of Orchids seeds. Bot Gaz 73: $1-25$

Kosir, P., Skof F and Luthar Z (2004) Direct shoot regeneration from nodes of Phalaenopsis orchids. Acta agric Slov 83: 233-242

Krikorian, A.D., 1982. Cloning higher plants aseptically cultured tissues and cells. Biol Rev 57: 151-218

Kull, T., Kindlmann P, Hutchings MJ and Primack RB (2006) Conservation biology of orchids: Introduction to the special issue. Biol. Conserv 129: 1-3

Kumari, P., George ST and Rajmohan K (2013) Influence of plant growth regulators on in vitro clonal propagation of dendrobium sonia 'earsakul'. J Bio Innov 2: 51-58

Kuo, H.L., Chen JT and Chang WC (2005) efficient plant regeneration through direct somatic embryogenesis from leaf explants of Phalaenopsis 'Little Steve'. In Vitro Cell Dev Biol Plant 41: 453456

Laws, S.N., 1995. Cut orchids in the world market. Floracult Int 5: 12-15

Lim, L.P., and Choong CW (2014) Sucrose concentration for optimum growth of Phalaenopsis deliciosa seedling growth. Int J Chem Env Biol Sci 2: 2320-4087

Lo, S.F., Nalawade SM, Kuo CCL and Tsay HS (2004) Asymbiotic germination of immature seeds, plantlet development and ex vitro establishment of plantlets of Dendrobium tosaense Makino a medicinally important orchid. In Vitro Cell Dev Biol Plant 40: 528-535

Martin, K.P., and Madassery JP (2006).Rapid in vitro propagation of Dendrobium hybrids through direct shoot formation from foliar explants and protocorm like bodies. Sci Hortic 108: 95-99

Mitsukuri, K., Mori G, Johkan M, Shimada Y, Mishiba KI, Morikawa T and Oda M (2009) Effects of explant position and dark treatment on bud formation in floret culture of Ponerorchis graminiflolia Rchb. f. Sci Hortic 121: 243-247

Morel, G., and Martin S (1952) Gue' rison de dahlias atteints d'une maladie a' virus. C.R. Acad Sci Paris 235: 1324-1325

Morel, G.M., 1960. Producing virus free Cymbidiums. Amer Orchid Soc Bull 29: 495-497

Murashige, T., and Skoog F (1962) A revised medium for rapid growth and bio-assay with tobacco tissue cultures. Physiol Plant 15: 473-497

Murdad, R., Latip MA, Aziz ZA and Ripin R (2010) Effects of carbon source and potato homogenate on in vitro growth and development of Sabah's endangered orchid: Phalaenopsis gigantean. AsPac J Mol Biol Biotechnol 18: 199-202

Murthy, H.N., and Pyati AN (2001) Micropropagation of Aerides maculosum Lindl. (Orchidaceae). In Vitro Cell Dev Biol 37: 223-226

Nasib, A., Ali K and Khan S (2008) an optimized and improved method for the in vitro propagation of kiwifruit (Actinidia deliciosa) using coconut water. Sci Hortic 94: 107-116

Niknejad, A., Kadir MA and Kadzimin SB (2011) In vitro plant regeneration from protocorms-like bodies (PLBs) and callus of Phalaenopsis gigantean (Epidendroideae: Orchidaceae). Afr J Biotechnol 10: 11808-11816 
Novotna, K.W., Vejsadova H and Kindlmann P (2007) Effects of sugars and growth regulators on in vitro growth of Dactylorhiza species. Biol Plantarum 51: 198-200

Nuraini, I., and Shaib MJ (1992) Micropropagation of orchids using scape nodes as the explant material. Acta Hortic 292: 169-172

Pant, B., and Thapa D (2012) in vito mass propagation of an epiphytic orchid, Dendrobium primulinum Lindl. Through shoot tip culture. Afr J Biotechnol 11: 9970-9974

Pawar, B.D., Jadhav AS, Kale AA, Chimote VP and Pawar SV (2012) Zeatin induced direct in vitro shoot regeneration in tomato (solanum lycopersicum L.). Bioscan 7: 247-250

Peixe, A., Raposo A, Lourenco R, Cardoso H and Macedo E (2007) Coconut water and BAP successfully replaced zeatin in olive (Olea europea L.) micropropagation. Sci Hortic 113: 1-7

Philip, V.J., and Nainar SAZ (1986) Clonal propagation of Vanilla planifolia (Salisb.) Ames using tissue culture. J Plant Physiol 122: 211-215

Puchooa, D., 2004. Comparison of Different Culture Media for the In Vitro Culture of Dendrobium (Orchidaceae). Int J Agr Biol 6: 884-888

Reddy, J., 2008. Biotechnology of Orchids.I.K. International, New Delhi, India

Rittirat, S., Thammasiri $\mathrm{K}$ and Te-chato $\mathrm{S}$ (2012) Effect of media and sucrose concentrations with or without activated charcoal on the plantlet growth of $P$. cornu-cervi (Breda) Blume \& Rchb. f. J Agri Technol 8: 2077-2087

Rotor, G., 1949. A method of vegetative propagation of Phalaenopsis species and hybrids. Amer Orchid Soc Bull 18: 738-739

Roy, J., and Banerjee N (2002) Rhizome and shoot development during in vitro propagation of Geodorum densiflorum (Lam). Schltr Sci Hortic 94: 181-192

Roy, J., and Banerjee N (2003) Induction of callus and plant regeneration from shoot tip explants of Dendrobium fimbriatum Lindl. Var. Oculatum H.K. f. Sci Hortic 97: 333-340

Roy, J., Naha S, Majumdar M and Banerjee N (2007) Direct and callus-mediated protocorm-like body induction from shoot tips of Dendrobium chrysotoxum Lindl. Plant Cell Tiss Org Cult 90: 3139

Seeni, S., and Latha PG (1992) Foliar regeneration of the endangered Red Vanda, Renanthera imschootiana Rolfe (Orchidaceae). Plant Cell Tiss Org Cult 29:167-172

Seeni, S., and Latha PG. (2000) In vitro multiplication and ecorehabilitation of the endangerd Blue Vanda. Plant Cell Tiss Org Cult 61: 1-8

Sharma, U., Rao VR, Mohan JSS and Reddy AS (2006) In vitro propagation of Dendrobium microbulon. A rich- A rare anthomedicinal herb. Indian J Biotechnol 6: 381-384

Sheelavanthmath, S.S., Murthy HN, Hema BP, Hahn EJ and Paek KY (2005) High frequency of protocorm like bodies (PLBs) induction and plant regeneration from protocorm and leaf sections of Aerides crispum. Sci Hortic 106: 395401

Shekarriz, P., Kafi M, Deilamy SD and Mirmasoumi M (2014) Coconut water and peptone improve seed germination and protocorm like body formation of hybrid Phalaenopsis. Agr Sci Dev 3: 317-322

Shim, S.W., Hahn EJ, Paek KY (2003) In vitro and ex vitro growth of grapevine rootstock ' $5 \mathrm{BB}$ ' as influenced bynumber of air exchanges and the presence or absence of sucrose in 
culture media. Plant Cell Tiss Org Cult 75: $57-62$

Singh, K., Gutgutia A and Gutgutia SK (2008) Prospects of commercial orchid cultivation in India. In: national conference on orchids: science and society, Bangalore, India, April 10-12, pp. 97

Sinha, P., and Jahan MAA (2011) Clonal propagation of Phalaenopsis amabilis (L.) BL. cv. 'Golden Horizon' through in vitro culture of leaf segments. Bangladesh J Sc Ind Res 46: 163-168

Sinha, P., and Roy SK (2003) Regeneration of an indigenous orchid, Vanda teres (roxb.) Plant Tiss Org Cult 13: 165-171

Sinha, P., Fatema K and Roy SK (2004) Micropropagation of Dendrobium cv. Thai beauty. Bangladesh J Life Sci 15: 13-18

Sivakumar, G., Yu KW, Hahn EJ and Paek KY (2005) Optimization of organic nutrients for ginseng hairy roots production in large-scale bioreactors. Curr Sci 89: 641-649

Steward, F.C., and Mapes MO (1971) Morphogenesis in aseptic cell cultures of Cymbidium. Bot Gaz 132: 65-70

Steward, F.C., Mapes MO and Mears K (1958) Growth and organized development of cultured cells: II. Organisation in cultured grown from freely suspended cells. Am J Bot 45: 705-707?

Suntibala, H., and Rajkumar K (2009) Micropropagation of Dendrobium trnaparens L. from axenic pseudobulb segments. Indian J Biotechnol 8: 448452

Talukdar, S.K., Nasiruddin KM, Yasmin S, Hasan L and Begum R (2003) Shoot proliferation of Dendrobium orchid with BAP and NAA. J Biol Sci 3: 1058-1062

Tanaka, M., and Sakanishi Y (1977) Clonal propagation of Phalaenopsis by leaf tissue culture. Amer Orchid Soc Bull
46: 733-737

Tasy, H.S., 2000. Use of tissue culture for the mass propagation of pathogen free plants. Plant Cell Rep 17: 670-674

Thomas, T.D., and Michael A (2007) Highfrequency plantlet regeneration and multiple shoot induction from cultured immature seeds of Rhynchostylis retusa Blume, an exquisite orchid. Plant Biotechnol Rep 1: 243-249

Tisserat, B., and Jones D (1999) Clonal propagation of orchids: In Hall, R.D. (Ed.): Plant Cell Culture Protocols. Methods in Molecular Biology, 111. Humana Press Inc., Totowa, NJ, USA, pp.127-134

Tokuhara, K., and Mii M (1993) Micropropagation of Phalaenopsis and Doritaenopsis by culturing shoot tips of flower stalk buds. Plant Cell Rep 13: 711

Tokuhara, K., and Mii M (2001) Induction of embryogenic callus and cell suspension culture from shoot tips excised from lower flower stalk buds of Phalaenopsis (Orchidaceae). In vitro Cell Dev Biol Plant 37: 457-461

U.S. Department of Agriculture, (2006) Floriculture and Nursery Crop Situation and Outlook Yearbook. Economic Research Service, Washington, DC

Van Winkle, S.C., and Pullman GS (2006) Achieving desired plant growth regulator levels in liquid plant tissue culture media that include activated carbon. Plant Cell Rep 22: 303-311

Verma, S.K., Yucesan BB, Sahin G, Gurel S and Gurel E (2011) Direct shoot regeneration from leaf explants of Digitalis lamarckii Ivan, an endemic medicinal species. Turk J Bot 1-7

Vij, S.P., Aggarwal S and Pathak P (2004a) Regeneration competence of Cymbidium Great Waltz $\times$ Valley flower roots: a study in vitro. J Orchid Soc India 18 109-115 
Vij, S.P., and Aggarwal S (2003) Regenerative competence of foliar explants: Vanda coerulea Griff. J Orchid Soc India 17: 73-78

Vij, S.P., Sembi JK, Verma J and Pathak P (2004b) In vitro rapid mass multiplication of Aerides multiflora, a floriculturally significant species. J Orchid Soc India 17: 63-68

Vij, S.P., Sharma V and Kaur S (1994) Foliar explant and orchid micropropagation: Vanda Kasem's Delight 'Tom Boykin'. J Orchid Soc India 8: 79-83

Vijaykumar, S., Rajalakshmi G and Kalimuthu K (2012) Propagation of dendrobium aggregatum by green capsule culture. Lankesteriana 12: 131135

Wimber, D.E., 1963. Clonal multiplication of Cymbidiums through tissue culture of the shoot meristem. Amer Orchid Soc Bull 32: 105-107

Wimber, D.E., 1965. Additional observations on clonal multiplication of Cymbidiums through culture of shoot meristems. Cymbidium Soc News 20: 7-10

Yildiz, M., and Er C 2002. The effect of sodium hypochlorite solutions on in vitro seedling growth and shoot regeneration of flax (Linum usitatissimum). Naturwissenchaften 89: 259-261

\section{How to cite this article:}

Dipika Sarmah, Swathi Kolukunde, Monoj Sutradhar, Brijesh Kumar Singh, Tapas Mandal and Nirmal Mandal. 2017. A Review on: In Vitro Cloning of Orchids. Int.J.Curr.Microbiol.App.Sci. 6(9): 1909-1927. doi: https://doi.org/10.20546/ijcmas.2017.609.235 